\title{
PSYKOLOGIENS KRITISKE HISTORIE OG FILOSOFI
}

Richard Walsh, Thomas Teo \& Angelina Baydala:

A Critical History and Philosophy of Psychology. Diversity of Context, Thought and Practice

Cambridge University Press, 2014

709 sider, $£ 29,99$ (paperback)

De tre britiske universitetspsykologer Richard Walsh, Thomas Teo og Angelina Baydala har skrevet en glimrende kritisk indføring i psykologiens filosofi og historie.

Den tyske filosof Friedrich Beneke regnes som en af den moderne videnskabelige psykologis forløbere. Da Beneke udgiver sin Lehrbuch der Psychologie i 1832, definerer han psykologien som en naturvidenskabelig disciplin, der beskæftiger sig med den indre erfaring. Beneke bliver dermed blandt de første, som artikulerer det naturvidenskabelige ideal, som kommer til at hænge ved store dele af den moderne psykologi fra 1800-tallet og frem. Idealet udgør sådan set allerede en væsentlig inspiration for 1600- og 1700-tallets filosofiske psykologi. I 1900-tallet bliver den naturvidenskabelige model især udgangspunkt for den anglo-amerikanske forståelse af psykologien. En forståelsesform, der har været dominerende siden 1930'erne. Det har den ikke mindst som en del af psykologiens generelle amerikanisering omkring og efter anden verdenskrig. I samme forbindelse er den amerikanske psykologi i løbet af de seneste 70 år blevet spredt til hele verden, hvilket har medvirket til den globale internalisering af det vestlige menneskesyn.

De samfunds-, human- og sundhedsvidenskabelige tilgange til psykologien har også haft en vis betydning. Disse tilgange har bare stået mere i skyggen af den naturvidenskabelige forståelse. Ifølge Walsh, Teo og Baydala, kan dette være med til at forklare, hvorfor den moderne psykologi har haft en udpræget tendens til at iscenesætte sig selv som en ahistorisk og afilosofisk disciplin. Det gør den moderne psykologi sådan set stadigvæk i et vist omfang. Ifølge trioen opfatter de fleste nutidige psykologer fortsat historie og filosofi som uvæsentlige for deres egen forskning og praksis. Her vil jeg så påpege, at der i disse år alligevel er begyndt at udkomme en stigende mængde interessant litteratur omkring netop det emne. 
Walsh, Teo og Baydala følger i den forbindelse en aktuel tendens til at anlægge en kritisk vinkel på emnet. Kritisk først og fremmest i den forstand, at trioen tager afstand en whig tilgang til psykologiens historie. Afstand fra fortællingen om en lineær fremadskriden mod det nuværende videnskabelige niveau, der er uafhængig af sociale og kulturelle forhold. Samtidig er trioen kritisk over for presentismen forstået som tendensen til at fortolke fortiden ud fra nutidens målestok. De falder desværre selv halvvejs i gryden. Ved at forsyne bogen med et stænk af feministisk ideologi og politisk korrekthed. Trioen bruger ikke mindst en del spalteplads på at fortælle om kvindernes historiske marginalisering og forandrede samfundsstatus. Forfatterne er til gengæld meget eksplicitte omkring dette udgangspunkt. Denne tydelighed kan ses som et led i deres hermeneutiske metode, og samtidig er det også befriende med forfattere, der bekender kulør i en påtaget holdningsløs forskningsverden. Samtidig formår de tre forfattere i et vist omfang at bevare et reelt kritisk fokus på, hvordan psykologiske idéer og aktiviteter kan forstås udefra. Uden at tage psykologien eller psykologiske tankeformer og begreber for givet. Med et blik for, hvordan psykologiens historie er dybt forankret i sociale og kulturelle forhold og derfor heller ikke er uafhængig af normer og værdier, moral og politik.

Det er efterhånden blevet et stadig mere kontroversielt idéhistorisk spørgsmål, hvornår og hvordan psykologien opstår. Den tyske filosof Rudolphus Goclenius udgiver i 1590 Psychologia Hoc Est, de Honis Perfectione, der gerne opfattes som det første egentlige psykologiske manuskript i den vestlige verden. Det er 234 år før at Preussen som det første land i verden i 1824 lancerer psykologi som et obligatorisk universitetskursus for undervisningskandidater. Eller 289 år før Wilhelm Wundt i 1879 etablerer verdens første psykologiske laboratorium på Universität Leipzig og dermed, ifølge den traditionelle whighistorie, grundlægger den videnskabelige empiriske psykologi. Walsh, Teo og Baydala følger imidlertid et helt fjerde - om end stadig populært - svar på spørgsmålet om psykologiens opståen. De sporer nemlig den vestlige psykologis historie helt tilbage til de førsokratiske filosoffer. Trioen vier derfor et ud af bogens tolv kapitler til den antikke og førmoderne psykologi. To yderligere kapitler omfatter oplysningen og den videnskabelige revolution samt det filosofiske og videnskabelige klima i det 19. århundrede. Vi får således en grundig idéhistorisk indføring i den sociale og kulturelle kontekst for psykologiens udvikling. Samtidig med at de tre briter bevarer et mere traditionelt blik for de store psykologer og deres store psykologiske idéer. 
Bogen vier en betragtelig del af de 709 sider til naturvidenskabernes udvikling og udviklingen af den naturvidenskabelige psykologi. Den nyeste udvikling inden for blandt andet evolutionspsykologien, kognitivismen og neuropsykologien får desværre en lidt overfladisk behandling. Psykologer og psykologistuderende vil til gengæld komme rigt i berøring med disse aktuelle emner i andre sammenhænge. Modsat idéhistorikere og filosoffer. Det er til gengæld en reel mangel, at dele af den humanvidenskabelige og samfundsvidenskabelige psykologis moderne historie bliver lovligt overfladisk behandlet. De to afsnit om hermeneutikken virker til gengæld nærmest overproportionerede, og det undrer mig især, at Wilhelm Dilthey tildeles mere opmærksomhed end hele den humanistiske psykologi. Men hermeneutik er i vælten.

Den britiske trio glimrer især ved at forsyne bogen med et kapitel om anvendt psykologi og et kapitel om psykologisk forskning. Den moderne psykologi er på flere niveauer et meget metodecentreret fagområde. Praksis- og forskningsetik spiller desuden en meget stor rolle. Det gælder især i angloamerikanske sammenhænge.

Endelig udmærker den fyldige bog sig ved at indeholde et afsluttende kapitel om kritisk filosofisk og historisk refleksion. Her får vi fint overblik over psykologikritikkens historie fra Immanuel Kant og frem. Den feministiske og postmoderne kritik får hver især et særafsnit. I tidens ånd får vi også et helt afsnit om postkolonialistiske perspektiver. Det angelsaksiske publikum er blevet multikulturelt, og bogen samler op på de nødvendige refleksioner i den forbindelse. Forfatterne vier halvanden side til deres vision for psykologiens fremtid. Den vision burde enten være udeladt eller uddybet mere. Det ændrer dog ikke ved, at bogen giver et godt overblik, er pædagogisk opbygget og særdeles velskrevet.

\section{Anders Droby Sørensen}

